\title{
Some Remarks on Immigrant Experience
}

\section{Aloysius M. Ambrozic}

Volume 50, numéro 2, 1983

Bilan de l'histoire religieuse au Canada

Canadian Catholic History: A survey

URI : https://id.erudit.org/iderudit/1007219ar

DOI : https://doi.org/10.7202/1007219ar

Aller au sommaire du numéro

Éditeur(s)

Les Éditions Historia Ecclesiæ Catholicæ Canadensis Inc.

ISSN

0318-6172 (imprimé)

1927-7067 (numérique)

Découvrir la revue

Citer cet article

Ambrozic, A. M. (1983). Some Remarks on Immigrant Experience. Sessions d'étude - Société canadienne d'histoire de l'Église catholique, 50(2), 499-511. https://doi.org/10.7202/1007219ar

Tous droits réservés @ Les Éditions Historia Ecclesiæ Catholicæ Canadensis Inc., 1983
Ce document est protégé par la loi sur le droit d'auteur. L'utilisation des services d'Érudit (y compris la reproduction) est assujettie à sa politique d'utilisation que vous pouvez consulter en ligne.

https://apropos.erudit.org/fr/usagers/politique-dutilisation/ 


\title{
Some Remarks on Immigrant Experience
}

\author{
by Aloysius M. Ambrozic \\ Auxiliary Bishop of the Archdiocese of Toronto.
}

I ought to begin this article by informing the reader that I came to Canada from my native Slovenia (Jugoslavia) at the age of eighteen, and that by "immigrant" I mean a person who leaves his native land after the age of seven or eight and settles in a country which speaks a different language. As introduction, I wish to tell you two stories and quote a passage from a novel. The first story is about a 'phone-call I received a few years ago in which a soft feminine voice told me her name and informed me that she had been appointed by the University of Toronto to foster contacts with ethnic communities. As soon as I heard this I broke out laughing. Become aware of the offended silence on the other side, I hastened to apologize and to explain my laughter by pointing to my surprise at the fact that the University of Toronto would deign to recognize the presence of immigrants - after their being on its door-step for some hundred and thirty years.

The second story is about a very intelligent and articulate Catholic woman, who told me that I was rather difficult to fathom. One reason for this was my opting for what in Toronto goes for a rather small parish when as a Bishop I could have had a larger one, and as an immigrant I would naturally want a rich one. I am certain she had no idea how offensive this unwitting display of nativeborn superiority really was.

The literary reference is to Vladimir Nabokov's Pnin (1953), the story of a Russian professor in the U.S. The final scene in the book is as follows:

"Hardly had I taken a couple of steps when a great truck carrying beer rumbled up the street, immediately followed by a small pale blue sedan with the white head of a dog looking out, after which came another great truck, exactly similar to the first. The humble 
sedan was crammed with bundles and suitcases; its driver was Pnin"' (pp. 190-191).

I cannot help but see in Pnin's car, untidily filled with all sorts of possessions, an intended symbol of the immigrant's erratic existence, caught between two self-assured civilizations, that of the country which he had left and that of the country in which he lives.

\section{MELTING POT, MULTICULTURALISM, ASSIMILATION}

\section{a. Inadequacies of these views}

In this book Protestant - Catholic - Jew: An Essay in American Religious Sociology (1955), Will Herberg touches on the 19th century discussion about the kind of nation America ought to become. One pole of this discussion was the melting pot theorists, the other the defenders of pluralism.

"The ideologists of the melting pot looked forward to a racial and cultural blending of all immigrant strains into a new synthesis... In sharp opposition, the nationalists agitated for the perpetuation of the ethnic communities as integral parts of American society; they often called it pluralism, but what they had in mind, whether they knew it or not, was the transplanting of the European multinational, multicultural society in America. Neither the assimilationists of the melting-pot nor the ethnic champions of pluralism gaged aright the dynamics of American life"' (p. 32).

While the champions of pluralism turned out to be quite mistaken, since "cultural assimilation began almost as soon as the immigrant touched these shores", it would also be mistaken to ascribe victory to the protagonists of the melting pot ideal, for the American's image of himself is not "a composite or synthesis of the ethnic elements that have gone into the making of the American." Rather, "the American's image of himself is still the Anglo-American ideal it was at the beginning of our independent existence" (pp. 32-33). Myrna Kostash, a second generation Ukrainian Canadian, would agree with Herberg :

"English is our mother tongue. Our understanding of the Ukrainian language is imperfect and our speech even worse. (If we are successful writers, speakers, teachers, actors and editors, it's because we have mastered the English language and excelled as members of an Anglophone community.) Not many of us bother going to 
church regularly, still less to a Ukrainian one and, when we do bother to observe an ethnic, religious festival, it's by means of a sentimental flurry at Christmas and at Easter. We are ignorant of and indifferent to Ukrainian history. We don't feel prejudiced against as Ukrainians and have better things to do with our time than participate in an ethnic organisation blathering on about 'discrimination' and 'rights'. We feel as Canadian as, and sometimes even more Canadian than, the next guy and, even if we aren't in the ruling class, we don't feel very hard done by. We enjoy Ukrainian music, dance, crafts and food but not much more than we enjoy Chinese food and classical ballet and much less than American movies and rock'n roll. The national origin of the person we marry is immaterial to our well being" 1

Will Herberg thinks, or thought in 1955, that the decreasing ethnic self-identification of large numbers of Americans is giving way to the triple melting pot of religious identification, of Protestants, Catholics and Jews. He may have been somewhat too quick, however, in relegating the ethnic consciousness of many to the past. Such a book as Michael Novak's, The Rise of the Unmeltable Ethnics: Politics and Culture in the 70's, (1972), though it may exaggerate at times, indicates that ethnic sensitivity and ways of perceiving reality do not disappear as easily as it seems and that, even if the language is long forgotten or unknown, family traditions, attitudes, humour and other traits persist much longer. The same is shown by Richard Gambino in Blood of My Blood: The Dilemma of the Italian-Americans (1974): the assimilation has not been as thorough as some tend to believe.

Though Stephen Steinberg has quite rightly questioned some of the exaggerations of those who have written about the persistence of ethnicity in America in his recent The Ethnic Myth: Race, Ethnicity, and Class in America (1981), he can, I feel, be accused of an ideological onesidedness which makes him unable to perceive and appreciate the fact that survival of ethnic behaviour patterns is not due solely to the poverty of some ethnics and the confining power of nativist prejudice. There are attitudes which are much too deeply ingrained to disappear in one or two generations, and this despite their having been separated from

'All of Baba's Children, Edmonton, Hurtig, 1977, p. 387. 
their natural habitat. Both Steinberg and Kostash can be accused of seeing continuing ethnic national sentiments merely as as outgrowth of material or social conditioning; those who experience these sentiments know they are much deeper and more "disinterested" than Steinberg and Kostash would allow.

In Canada we can foresee a development similar to that of the U.S., with the distinction that in Canada there are two foundational cultures. Our present policy of multicuituralism is, for all its vagueness, an immensely useful phenomenon, not as a programme for the future shape of Canada primarily but as a means of palliating social and psychic pressures and of preventing complexes in the immigrants and their children. It will undoubtedly contribute to the preservation of certain cultural elements, in ways which we cannot as yet perceive and explore.

It is obvious, of course, that only two cultures have any chance of survival as recognizable entities, namely, the English and the French. To live, a culture needs a population inhabiting a definite territory, an economic base, an educational system, a media network, etc. - in Canada it is only the English and the French, and possibly the Indian and Eskimo cultures which have these means at their disposal. Harsh as it may sound, it must be said that other cultures will disappear as independent and recognizable realities, if immigration ceases:

" ...the cruel point, which has the force of a brute fact of nature, is that a transplanted culture is a doomed one which dies visibly day by day. Literally: writers and their audience died; their ranks were not replenished; children in exile did not grow up into the language and culture of their parents but rather into that of their hosts." 2

Nonetheless a number of thought and behaviour patterns cannot help but survive and seep into the dominant cultures. Should immigration cease, these patterns will cease to be associated with their countries and cultures of origin and will become part and parcel of Canadian existence.

\footnotetext{
${ }^{2}$ Saul Maloff, "Vladimir Nabokov: The Emigre." Commonweal, January 6, 1978, p. 18 .
} 
It would seem fair to say that no description of the immigrant fact has yet been produced which does justice to it. Neither is the melting pot theory adequate nor that of multiculturalism; nor does it seem that assimilation is what takes place, no matter how credible it is on the surface.

I have no theory to offer beyond suggesting that each of the three contains some truth. I would wish, however, to indicate one element which seems to be missing.

\section{b. A missing element}

Besides their being inadequate descriptions of what happens to the immigrant in North America, $I$ feel that the three theories suffer from another weakness: they are being formulated from the point of view of the country of adoption and/or the country of origin. These do not look at the immigrant himself, precisely as immigrant. Instead, they look upon him primarily as an extension of themselves, as material to be shaped according to their wishes and needs; they impose upon him their own expectations and ideals. The immigrant seems to be, like Prof. Timofey Pnin's little car, squeezed between two heavy-laden beer trucks. The country of origin may look upon him with a certain amount of sadness as lost human potential; or it may look upon him as a possible source of economic or political advantage; it sees him growing quaint as his language tends to remain stagnant, tinged by dialect and more and more awkward. The new country tends to see him as new human material to be shaped and moulded into its own patterns, as a threat, as someone to be tolerated and utilized or, somewhat condescendingly, as contributing something of his own to his new home.

Yet this is hardly the way in which the immigrant looks upon himself. To make a personal remark, I am somewhat tired of the statements issuing from the lips of our leading personalities who tell ethnic gatherings how much ethnic groups are contributing to Canada. What annoys me more, however, is the willingness of many ethnics to squirm pleasurably whenever such compliments are made.

\section{IMMIGRANT EXPERIENCING HIMSELF}

The question we ought to ask is how the immigrant experiences himself, his life in the new country, his relationship to the new country and the country of origin, his needs and expectations, etc. Yet as soon as I make this suggestion I hesitate, since the immigrant's 
conceptualization and articulation of himself, his life and his relationships are generally determined by the culture he has left and the culture into which he has arrived. The thoughts and words by means of which he expresses himself to himself and to others are provided by the environments into which he has been placed. These environments, however, being stable and growing organically, cannot provide him with thought-categories which neatly fit his experience. To give an example, the immigrant will, indeed, contribute to the new country, but only on condition that he devotes no energies to it. For in order to have something to contribute he must, at the early stages of his immigrant existence, concentrate on remaining himself, on retaining the culture in which he was nurtured, and on keeping it alive for his children. Should he wish to contribute to his new homeland from the very beginning, he will try to please his hosts and thus lose his identity and whatever he might have to contribute. Another example: I recall the weepy literature about immigrants I read in my pre-immigrant days; I smile at the thought of it, for I fail to experience the great sense of loss or alienation from my roots depicted in those novels and poems; I do not pine away, longing for another sight of the valley in which I grew up. Before I wax too ironic, however, I must hasten to admit there are strings in my being which will throb only to the strains of Slovenia.

The difficulty is that nobody sets out to be an immigrant, in the sense of being a transitional being. No one is born as an immigrant and no one reproduces himself as such. It is a fate imposed on him, remaining very much his own. As immigrant he is understood fully neither by his father nor by his child, for they are both born into stable societies, and are not obliged to uproot themselves and begin a new existence in a foreign country. Thus the immigrant is not inclined to search for new categories to describe himself and his existence, nor do others help him to do this. He is, furthermore, generally much too busy making a living to indulge in introspection. Social sciences, psychology as well as history presuppose a certain stability; highly aware as they might be of change, progress and development, they seek, and because they seek they find, the permanent and the organic in the evolving world, the natural so to say, the predictable, what can be calculated and expected to happen. The immigrant's existence, however, has been cut in two and delivered to unforeseeable and unpredictable flux. In certain respects he has thrown himself into uncharted chaos. Chaos may seem too strong a term for what he encounters, for his new home is generally anything but chaotic, yet, to a degree at least, it is chaos to him. The language of the new 
country is not his;being meaningless at the beginning of his sojourn, the reality it describes is to a degree meaningless. He experiences himself as an infant, envying children chattering with ease and swimming effortlessly in the environment created by their language. The customs, feasts, enthusiasms, sense of humour, priorities, history, taken-forgranted and wordlessly presupposed ways of behaving in public and in private, all this is different to a degree, poorly understood or misunderstood and upsetting. Language is only the most evident element of strangeness in a confusing context.

The immigrant has a very sharp and at times painful brush with history and his own historicalness; he is deprived, all of a sudden, of many elements of his existence which up to then appeared permanent and were hardly thought of because taken for granted. He may prepare for it, but no preparation is adequate. With many supports pulled from under him, he discovers the fleetingness of his existence. Might not this very fleetingness be the stuff of history and thus of historiography? However, our desire to study what endures visibly and tangibly, and thus to partake of the permanence of things, is very natural and understandable. The immigrant as immigrant is, for that reason, not an attractive subject, for as immigrant he does not endure. Yet the immigrant ought to be studied for his own sake. First, because immigration is an important and widespread phenomenon of the contemporary scene; secondly, because all human existence is fleeting - in the immigrant we may perceive clearly what is less evidently true of all of us; thirdly, because fleetingness is not all there is to him. He is a human being who experiences, endures, develops defences against, and draws profit, often unknown to himself, from this fleetingness. As such a human being he does perpetuate himself; he does pass on his subborn perseverance, his fatalist optimism, his self-confident egalitarianism, his alienation and his pain.

\section{IMMIGRANT'S RELATIONSHIPS}

\section{a) The country of origin}

By the very fact that he moves away from his country of origin, the immigrant modifies his relationship with it. Though modified, the relationship is by no means severed: while the country of origin may lose strictly legal claims on him, it retains others, more profound and binding. He knows himself bound to the "old country", and manifests this awareness in many ways. This is most evident in the 
case of the political and ideological refugee, but it is also true of the economic immigrant. He remains in touch with his relatives, friends and neighbours whom he has left behind; only gradually does he change or shed the political allegiances and passions which animated him in his native land; for a long time he continues to follow the successes and failures of his favourite soccer team; he sends money to the old country, he is proud of it, he visits it and takes his children along.

The influence exerted on the country of origin by the immigrant communities abroad may be considerable. In the past, these communities may have contributed to the growing national awareness of certain late-maturing European nations. ${ }^{3}$ Political movements active abroad often exert decisive influence on developments in the countries at which they are aimed. The most evident examples are Lenin and Ayatollah Khomeini. Ethnic groups serve as beacons of freedom to their native lands, by being a living reminder to the people who stayed behind that other social and political structures are possible besides the one in which they are forced to live.

People who leave their native land generally possess, in a large measure, the ability to lead, or readiness to risk, or talent, or courage. The ideological emigrant was visibly committed to a cause in his country of origin, he exposed himself to danger and exercized leadership. The economic emigrant manifests at least the courage to sever the many bonds tying him to his home, family and native land as well as an ability to strike out on his own.

Clearly the immigrant will not, indeed cannot, change overnight. He brings with him the social, political, and cultural attitudes of his native land. Thus someone coming from a traditionally Catholic country, where Christian Democratic parties are part and parcel of the political horizon, will find it somewhat difficult to understand the kind of separation of Church and State characteristic of North America. Likewise, certain waves of post-war immigration to Canada will continue to view

\footnotetext{
${ }^{3}$ See Will Herberg, Protestant-Catholic-Jew, pp. 23-28.
} 
the NDP and its socialism with some suspicion. To mention another example, there is quite a difference between various ethnic groups in regard to their attachment to their language and efforts to pass it on to their children: some nationalities are more clearly aware of the language as a means of their self-identification.

It would be difficult, if not impossible, to spell out with much precision the changing relationship of the immigrant to his native land. Change it does; the length of his absence works its effects. His mothertongue tends, with years, to become less limpid and fluent than it was when he lived and breathed in its embrace, for the atmosphere in which he moves now lives out of another language and mentality. His image of the old country tends to remain fixed at the moment when he left; a visit after a number of years may be a shock. ${ }^{4}$ Of his tendency to idealize it, more shall be said below.

\section{b) The country of adoption}

The immigrant's attachment to the country of adoption is, during the first years of his sojourn, seldom profound or strong. The political refugee tends to look upon it as a refuge and a base of operations, which he appreciates and to which he may be grateful, but where he has little intention of striking roots; the economic immigrant looks upon it as a better opportunity to prosper materially. The country of adoption is chosen more or less fortuitously: my own family came to Canada because the U.S. was not ready to accept us yet, and we wanted to get out of a Europe which was ravaged by war and where we feared Russian invasion or forcible repatriation to Jugoslavia. With the passage of years, however, with the birth and growth of children, with the gradual "getting used to" the new environment and absorbing its way of living, working and thinking the immigrant will, in a manner hardly noticed by himself, gradually develop loyalty to and pride in his adoptive country. This loyalty will be of a more rational kind, less instinctive than that characteristic of the native-born; it is nonetheless genuine and permanent.

\footnotetext{
${ }^{4}$ See Ted Kramolc, "Fotoalbum”, Meddobje, 1982, pp. 72-77.
} 
Yet no matter how well integrated or assimilated he may be, the immigrant carries a world within himself which is very much his own and which, though he may not admit it even to himself, is condemned to death. He will never be fully at home in the new country: he may learn a great deal, he may adapt very well, outwardly he may function as well as the native-born, yet there are elements within him which do not fit into the country of adoption, despite its real or pretended broadmindedness and pluralism. There are memories he can share with very few - this happens to everyone with the passage of years, of course, but to the immigrant it happens early in life and in ways that can be more upsetting and disturbing. His inevitable isolation is one of the many signs that his world is condemned to death.

Like all human beings he tries to cheat death, to rob the moment of its momentariness, to hold on to himself, to endure; but he experiences this desire more poignantly since a number of elements which seem to assure the tangible and visible immortality no longer surround him, such as the corner of the world into which he was born seemingly so firm and permanent. He tries to imitate and preserve this world. It is almost an instinctive reaction against the slings and arrows of the new environment to idealize the country of origin. In this regard too he could be said to be prematurely old; in reality, he is trying to remain himself. $\mathrm{He}$ is forced to live in a "demythologized" landscape, in a world which he has encountered after having attained the use of reason. His country of adoption is not perceived through the immensely sensitive and receptive eyes of a child but in a more rational and utilitarian manner. The land he buys and sells has no aura of sacredness and family trust which shimmers over many a farm in the old country.

The ethnic community, or ghetto - what we call it will depend mostly on our attitude toward it, is the most visible of the immigrant's defences against death. Whether it be geographic or social, it is indispensable for most members of the first generation and, to a degree, even for many of the second generation - for very little can be preserved or clung to in isolation. Ghettos have admittedly, and sometimes deservedly, enjoyed a bad press. Their negative aspects need hardly be mentioned, such as their narrowness, their failure to live in tune with the environment, to understand the young, to develop the sense of responsibility for the country of adoption. Ghetto tends to be fractious and faction-ridden - the emotions made for larger contexts must spend themselves in a narrow space. It threatens to become the immigrant's only home, for he cannot grow naturally with his country of origin and may not be developing with the country of adoption. In spite of 
all this, it must be kept in mind that ghetto arises out of the need to belong to a group larger than one's family and the need of an identity which is more intimate than "national." The immigrant needs it in order to remain an integral human being; it protects him from the kind of assimilation which entails a brusque sloughing off of the old skin in favour of one which does not fit; it offers the immigrant's child the opportunity to grow up without too many painful gaps between the world of his fathers and the new world. In the difficulties which the immigrant's child meets in his attempt to live with two worlds within himself, it is better that he have peers whose experience is similar to his than to be surrounded entirely by those whose background has not attuned them to his predicaments and tensions. The immigrant ghetto is a sign of healthy resistance of human beings to being smothered by the wellintentioned majority with its uniformity and self-confident superiority. In this connection, we should mention the interesting fact that the immigrant is seldom a cosmopolitan. He cannot afford to be one; having lost his home, he feels its significance too keenly. Only those who feel very securely "at home" can permit themselves cosmopolitan posturing with any degree of sincerity.

Another indication of the precarious nature of immigrant existence is his need to show that he has not gone under, whether it be by boasting, showing off, large tomb-stones, or, as in the vast majority of cases, by incredibly hard work. It ought to be pointed out also that the immigrant's generosity is at least as great as that of the native-born; his priorities, however, are different. The concerns of the country of origin, economic, social, cultural as well as religious, continue to preoccupy him. These concerns give a dimension to Canadian life and a reputation to Canada of which Canada is often unaware or unconcerned.

Slightly ridiculous at times, in danger of being a figure of fun both in the country of origin and in the country of adoption, hiding from himself a pain and a sadness stemming from unharmonizable dissonances within his experience - this is the immigrant. "In the morning went to Congress of Free Journalists at the Dorchester. Quite a large gathering, rather pathetic in a way like all gatherings of exiles." 5

${ }^{5}$ Like it was: The Diaries of Malcolm Muggeridge; selected and edited by John Bright-Holmes; London, 1981, p. 363. 
It would be a mistake, however, to imagine that this note of sadness is the dominant feature of immigrant existence. The immigrant is anything but a sad person. And even the causes of sadness generate compensating advantages. Emigration is, to begin with, liberation, at least in certain respects: the emigrant is allowed to shed the outer constraints, pressures and restrictions of the country of origin, while some of the demands and exigencies internalized by those born in the new country do not bind him as yet. Thus he is freer to strike out on his own and to imagine; forced to be different, he is freer to do something different. The new country moreover, though neglectful of his many needs, is somewhat indulgent towards him because it does not consider him to be a fully mature and responsible member of society. Thus it is that at times it is the outsider who sees and seizes beckoning opportunities which the nativeborn do not perceive.

The outer and the inner freedom is necessarily accompanied by a kind of independence: the immigrant is obliged to find a way for himself in areas which are, to him, uncharted. This independence, thrust upon him, is seldom an enjoyable experience, since confusion and fear are often part and parcel of it. Yet many a so-called ordinary man will take on social functions within the ethnic community which, in established societies, are carried out by professional, cultural and social elites. Natural leaders emerge who would never have thought of coming forth within stable social contexts of the old and new countries. This tends to give rise to self-confidence and to an at times abrasive egalitarianism of the self-made man.

A breadth of vision is also forced upon the immigrant: not only is he learning about another country and culture but is obliged to live and work in it. His vision, having nothing abstract or bookishly idealized about it, is rather mature, though seldom very articulate or introspective. Feeding as it does on two lived perspectives of reality, it can change dimensions of things, dampen enthusiasms, reduce hostilities and fears. This realism will seldom descend into cynicism, partly because it is too mature and partly because it is only the very safely positioned who can afford such luxuries.

Immigration unlocks energies which, at home, would have lain dormant. His willingness to risk, repeatedly tested and generally crowned with some measure of success, becomes part of his make-up, and is passed on to his children. It should be said in this connection that, though his economic success is more noticeable and more frequently 
commented upon, it is neither his only kind of success nor the one primarily striven for. At times it is the only kind of success permitted him in the country of adoption. ${ }^{6}$

\section{CONCLUSION}

The immigrant existence reminds me of the following thought of Milan Kundera:

"This is the great private problem of man: death as the loss
of self. But what is this self? It is the sum of everything we
remember. Thus, what terrifies us about death is not the loss
of the future but the loss of the past. Forgetting is a form of
death ever present within life... But forgetting is also the great
problem of politics. When a big power wants to deprive a small
country of its natural consciousness it uses the method of
organized forgetting." 7

The immigrant's effort to remain what he is, his seemingly premature clinging to memories of the past and idealizing his native land, his conscious attempts to pass on what he is to his children - all this stems from his brush with mortality in the abrupt loss of the steadying hand of the familiar and accustomed, a loss which he suffers much earlier in life than most other people. He may tend to become rigid, and resistant to change, to exhibit what seems to be a one-track mind; but he is also wiser, less liable to fall prey to ephemeral enthusiasms. Seldom naive or credulous, he may seem to be, and sometimes is, selfish and hard-boiled, but he can also be more understanding and more deeply aware of the human condition.

We could speak of the immigrant as a secular pilgrim who, having left his home, is constantly searching for another one without ever finding it. He comes closer and closer, but never makes it. He is condemned to being a stranger, no longer at home in his first home and never quite at home in his new home. His is not an experience entirely unknown to others, for everyone of us is, to a degree, a stranger wherever he might be. But it is an experience which is lived not read about, his not vicarious, true not bookish, and thus more genuine.

\footnotetext{
${ }^{6}$ See Jean Bruce, After the War, Toronto, 1982, pp. 30-32.

${ }^{7}$ The Book of Laughter and Forgetting, Harmondsworth: Penguin, 1981, pp. 234-235.
} 